\title{
TUMBUHAN HERBAL SEBAGAI JAMU PENGOBATAN TRADISIONAL TERHADAP PENYAKIT DALAM SERAT PRIMBON JAMPI JAWI JILID I
}

\author{
Hesti Mulyani, Sri Harti Widyastuti, dan Venny Indria Ekowati \\ Fakultas Bahasa dan Seni Universitas Negeri Yogyakarta \\ email: hesti_mulyani@uny.ac.id
}

\begin{abstract}
Abstrak: Tumbuhan Herbal sebagai Jamu Pengobatan Tradisional terhadap Penyakit dalam Serat Primbon Jampi Jawi Jilid I. Penelitian ini bertujuan untuk mendeskripsikan dan menganalisis tumbuhan herbal yang dimanfaatkan sebagai pengobatan tradisional terhadap penyakit dalam manuskrip Jawa, yakni Serat Primbon Jampi Jawi Jilid I (SPJJ I) koleksi Reksapustaka Mangkunegaran Surakarta. Metode yang digunakan adalah deskriptif-analitis dengan pendekatan filologi modern. Pendekatan filologi modern digunakan untuk membedah manuskrip SPJJ I. Deskripsi dilakukan untuk tumbuhan herbal yang bermanfaat sebagai pengobatan tradisional terhadap penyakit dan analisis kandungan beserta khasiatnya. Hasil penelitian dan pembahasan menunjukkan bahwa tumbuhan herbal yang ditemukan terdiri atas akar, rimpang, umbi, kulit kayu, batang, daun, bunga, buah, dan biji. Di samping itu, juga ditemukan bahan-bahan jamu sebagai pelengkapnya, yaitu, garam, inggu, tembakau (sata awon), air jeruk nipis, air jeruk purut, air perasan daun iler, air susu ibu, air tawar: dingin, panas, dan cuka. Cara pengolahan bahan racikan jamu, yaitu dibakar, digigit-gigit, digoreng, dihaluskan (dipipis, didheplok, digerus), dijemur, dikukus, direbus, dan direndam. Adapun cara pemberian jamu, yaitu di-borèh-kan, di-cekok-kan, diminumkan, di-param-kan, di-pupuk-kan, dan di-tapel-kan.
\end{abstract}

Kata kunci: tumbuhan herbal, pengobatan tradisional terhadap penyakit, manuskrip Jawa, filologi modern

\begin{abstract}
Herbs as Traditional Medicine Jamu of the Disease in Serat Primbon Jampi Jawi Jilid I. This study was aimed at describing and analyzing the herbs which are used as traditional medicine against the disease in Javanese manuscripts, namely Serat Primbon Jampi Jawi Jilid I(SPJJ I) Mangkunegaran Surakarta Reksapustaka collection. The method used was descriptive-analytic approach and modern philology. The approach used to analyse the manuscript was modern philology. The description is conducted for herbs that are beneficial as the traditional treatment of disease and analysis of the content and its usefulness. The result shows that herbs consist of roots, rhizomes, bark, stems, leaves, flowers, fruits, and seeds. In addition, herbal ingredients as complementary, ie, salt, rue, tobacco (sata awon), lemon juice, juice of lime, the juice of the leaves slobber, breast milk, fresh water: cold, heat, and vinegar. The process are varied such as by being burned, bitten, fried, mashed (crushed), dried, steamed, boiled and soaked. As for making herbal medicine jamu are by boreh, cekok, drunk, param, pupuk, and tapel.
\end{abstract}

Keywords: herbs, traditional medicine against the disease, Javanese manuscripts, modern philology 


\section{PENDAHULUAN}

Artikel ini merupakan bagian dari penelitian kelompok yang bertujuan untuk melestarikan isi manuskrip (teks) Jawa, yakni primbon. Tujuan tersebut diwujudkan dengan mendeskripsikan dan menganalisis tumbuhan herbal yang berhubungan dengan pengobatan tradisional terhadap penyakit yang dimuat dalam sumber data berupa manuskrip Jawa. Manuskrip (naskah) adalah karangan tulisan tangan nenek moyang, baik yang masih asli maupun salinannya, ditulis dengan aksara daerah. Jawa adalah nama pulau yang dihuni oleh masyarakat yang melestarikan suatu tradisi dari waktu ke waktu. Jadi, manuskrip Jawa adalah karangan tulisan tangan nenek moyang Jawa, baik yang masih asli maupun salinannya ditulis dengan aksara Jawa. Berisi uraian tentang suatu tradisi (Baried, dkk., 1994: 1-3, 55), dalam hal ini tradisi pengobatan tradisional terhadap penyakit.

Isi yang dimuat di dalam manuskrip disebut teks. Manuskrip dan teks merupakan objek kajian filologi. Berdasarkan teori yang ada didapatkan definisi kata filologi. Kata Filologi berasal dari bahasa Yunani philologia merupakan gabungan dari kata philos berarti 'cinta'dan kata logos berarti'kata' (Baried dkk., 1985: 1). Pengertian kata-kata tersebut berkembang menjadi'senang belajar', 'senang ilmu', dan 'senang kesusastraan' atau 'senang kebudayaan'. Selanjutnya, Baried dkk. (1994: 4) menyatakan bahwa filologi adalah suatu suatu ilmu kemanusiaan sebagai sarana untuk menguraikan hasil budaya masa lampau yang masih disimpan sebagai warisan berupa karya tulis. Dengan demikian, filologi adalah salah satu disiplin ilmu termasuk dalam ilmuilmu humaniora (kemanusiaan) (Istanti, 2010: 16).
Istanti (2010: 16) menguraikan bahwa filologi adalah salah satu disiplin ilmu yang dibutuhkan sebagai sarana untuk menguraikan nilai-nilai kehidupan zaman dahulu yang dimuat di dalam warisan berupa tulisan sebagai hasil kebudayaan manusia zaman dahulu. Hasil kebudayaan manusia zaman dahulu adalah hasil dari buah gagasan, perasaan, kepercayaan, kebiasaan, dan nilai-nilai yang digunakan oleh masyarakat masa itu. Pendapat tersebut sejalan dengan pendapat Saputra (2008: 79) yang menyatakan bahwa filologi adalah studi tentang hasil kebudayaan zaman dahulu (masa lampau) melalui manuskrip dan teks. Djamaris (2002: 3) menyatakan bahwa filologi salah satu ilmu sebagai sarana untuk meneliti manuskripmanuskrip lama.

Berbagai penelitian terhadap manuskrip Jawa telah banyak dilakukan. Namun, masih banyak manuskrip yang belum disentuh. Sementara pengetahuan yang ada di dalamnya merupakan pengetahuan yang penting dan dibutuhkan masyarakat. Artikel ini mendasarkan pada langkah kerja penelitian filologi modern. Pada langkah awal menghasilkan inventarisasi sejumlah lima eksemplar manuskrip yang berisi tentang fitoterapi pada manuskrip-manuskrip yang tersimpan di perpustakaan Reksapustaka Mangkunagaran Surakarta, salah satunya adalah Serat Primbon Jampi Jawi jilid I (SPJJ I).

Selanjutnya, dilakukan deskripsi naskah yakni mendeskripsikan keadaan naskah sejelas-jelasnya agar tergambar keadaan dan umur naskah. Kemudian, telah dibuat transliterasi teks secara standar. Selanjutnya, dilakukan terjemahan teks dan pengklasifikasian. Dari hasil klasifikasi didapatkan kategorikategori yang disimpulkan dari analisis data. Kategori tersebut meliputi bahan 
tumbuhan herbal, kandungan, dan khasiat atau manfaatnya.

Tumbuhan herbal adalah tumbuhan atau tanaman obat yang dapat dimanfaatkan untuk pengobatan tradisional terhadap penyakit. Sejak zaman dahulu, tumbuhan herbal berkhasiat obat sudah dimanfaatkan oleh masyarakat Jawa. Pengobatan tradisional terhadap penyakit tersebut menggunakan ramuanramuan dengan bahan dasar dari tumbuhtumbuhan dan segala sesuatu yang berada di alam. Sampai sekarang, hal itu banyak diminati oleh masyarakat karena biasanya bahan-bahannya dapat ditemukan dengan mudah di lingkungan sekitar (Suparmi \& Wulandari, 2012: 1). Pengobatan tradisional terhadap penyaktit dengan tumbuhan herbal atau sering disebut fitoterapi atau pengobatan dengan jamu merupakan pengobatan tradisional khas Jawa yang berasal dari nenek moyang.

Masyarakat Jawa merupakan masyarakat yang menjadi penjaga tradisi yang sangat kuat. Namun demikian, pemakai obat tradisional diharapkan sabar dalam melakukan terapi, baik pada saat memilih ramuan maupun menggunakannya (Rahimsyah \& Hartatik, 2006: 2). Sampai sekarang, pengobatan tradisional terhadap penyakit dengan penggunaan obat tradisional yang lebih dikenal dengan jamu terus dilestarikan oleh masyarakat modern (Arisandi \& Andriani, 2011).

Pengobatan tradisional pada awalnya merupakan tradisi turun-temurun yang disampaikan secara lisan dari satu generasi ke generasi berikutnya. Seiring dengan dikenalnya tradisi tulis di Indonesia, maka pengobatan tradisional yang awalnya merupakan oral tradition, akhirnya dituliskan. Sampai sekarang, tulisan-tulisan kuna oleh nenek moyang bangsa Indonesia tersebut tersimpan di museum-museum dan perpustakaanperpustakaan di Indonesia dan luar negeri. Tulisan tersebut dikenal dengan sebutan naskah atau manuskrip.

Berkaitan dengan tujuan pembangunan kesehatan yang tertera di dalam GBHN dituliskan demikian "meningkatkan kemampuan untuk hidup sehat dan mampu mengatasi masalah kesehatan sederhana terutama melalui upaya pencegahan dan peningkatan upaya pemerataan pelayanan kesehatan". Hal itu dilakukan dengan maksud agar terjangkau oleh masyarakat sampai ke pelosok pedesaan, maka upaya pengobatan tradisional merupakan suatu alternatif yang tepat sebagai pendamping pengobatan modern (Zulkifli, 2004: 1).

Undang-Undang Nomor 9 Tahun 1960 tentang Pokok-Pokok Kesehatan pasal 2 ayat 4 yang berbunyi: Usaha-usaha pengobatan tradisional berdasarkan ilmu atau cara lain daripada ilmu kedokteran diawasi oleh pemerintah agar tidak membahayakan masyarakat. Selanjutnya, Undang-Undang Kesehatan Nomor 23 Tahun 1992 pasal 47 dinyatakan bahwa pengobatan tradisional mencakup cara, obat, dan pengobatan atau perawatan dengan cara lainnya dapat dipertanggungjawabkan.

Dalam kehidupan dari zaman dahulu sampai sekarang dikenal adanya cara pengobatan. Cara pengobatan yang telah dilakukan di kalangan masyarakat, yakni cara pengobatan timur yang bersifat alternatif yang disebut pengobatan tradisional. Cara pengobatan itu bertujuan untuk meningkatkan sistem imun, menghambat pertumbuhan penyakit, mengurangi keluhan pengguna, dan memperbaiki fungsi badan tubuh (Zulkifli (2004: 1). Lebih lanjut, dituliskan bahwa pengobatan tradisional diharapkan berkembang bersama pengobatan modern supaya dapat saling mendukung dalam 
memberikan pelayanan kesehatan yang optimal pada masyarakat. Pengobatan tradisional yang disimpan di dalam manuskrip Jawa ini sengaja diteliti karena memuat informasi yang bermanfaat bagi kehidupan masyarakat masa kini.

\section{METODE}

Metode penelitian yang digunakan adalah deskriptif-analisis dan filologi modern. Untuk mengungkap isi suatu manuskrip disebut dengan metode penelitian filologi. Melalui filologi, maka suatu manuskrip dapat dikaji, sehingga dapat digunakan sebagai sumber data yang mantap. Manuskrip merupakan objek penelitian filologiyang diteliti dengan langkah kerja penelitian filologi, yakni inventarisasi manuskrip, deskripsi manuskrip, membaca teks, alih tulis teks dari aksara Jawa ke dalam aksara Latin, menerjemahkan teks, dan menganalisis isi teks. Berdasarkan langkah kerja penelitian filologi tersebut semua hal yang ditemukan sesuai dengan tujuan penelitian, yakni tumbuhan herbal untuk pengobatan tradisional terhapad penyakit disajikan secara deskriptif dan selanjutnya dianalisis.

\section{HASIL DAN PEMBAHASAN}

Berdasarkan data pada kategorisasi pengobatan tradisional Jawayang dimuat di dalam manuskrip Jawa SPJJ I (nomor jamu 234- 237; 367-368;391; 324, 328, 329, 89, $344,358,307-311 ; 342,343,345,346,351$, $354,359,360 ; 177,182-185 ; 194,208,212$, 228; 211 ditemukan jenis penyakit badan. Pada penyakit badan ditemukan bahan jamu dalam ramuan/resep jamu, cairan untuk campuran bahan jamu, pelengkap bahan jamu, cara pengolahan bahan, dan cara pemberiannya terhadap penderita. Berikut ini diuraikantemuan pengobatan tradisional Jawa yang terjangkau yang berhubungan dengan penyakit anak-anak yakni penyakit badan.

Tanaman obat atau tumbuhan herbal yang ditemukan terdiri atas akar, rimpang, umbi, kulit kayu, batang, daun, bunga, buah, dan biji. Adapun deskripsi tumbuhan herbal yang ditemukan di dalam manuskrip SPJJ I adalah sebagai berikut. Dalam manuskrip SPJJ I nomor jamu 329 halaman 115 ditemukan pemanfaatan akar dringo. Dringo atau dlingo disebut juga dengan jeringau (acorus calamus), akarnya bersifat afrodisiak, aromatik, karminatif, ekspektoran, stimulan, sedatif, diaforetik, emmanagogue, psikotropik, dan halusinosik. Khasiat akar dringo adalah dapat untuk mengobati bronkitis, gangguan lambung, limpa, artritis, diare, epilepsi, sinusitis, jika diseduh atau dibuat menjadi teh herbal dapat menyegarkan badan, dan sebagai neuroprotektif untuk mencegah serangan stroke pada sel syaraf otak (Tim Penyusun, 2012: 345).

Dalam manuskrip tersebut ramuan jamu secara lengkap terdapat pada nomor jamu 329 adalah sebagai berikut. Angka 329 Tapelipun: Rasuk angin 3 saga, secang 3 saga, widara pethak 4 saga, kencur 3 saga, brambang 2, dringo saros dariji, benglé 3 iris, adas 3 jodho, pulasari 2 ros dariji, oyot dringo panjangipun 3 nyari, temu lawak 3 iris, godhong urat $3 \mathrm{lb}$, dipunpipis mawi sarem 3 wuku, toyanipun cokak lajeng katapelaken. Akar dringo digunakan untuk menyembuhkan penyakit terkena sarab wedang (penyakit perut pada anak-anak), yakni digunakan sebagai salah satu bahan racikan jamu untuk tapel. Cara pengolahannya adalah akar dringo beserta racikan jamu yang lainnya dihaluskan kemudian di-tapelkan.

Rimpang yang ditemukan untuk penyakit badan dalam manuskrip SPJJ 
I adalah rimpang bengle, dringo, jahe, kencur, kunci, kunyit, lempuyang, sunthi, dan temulawak. Bengle (Jawa) atau bangle (Hidayat \& Napitupulu, 2015: 45) nama Latinnya adalah zingiber cassumanar. Efek herbal rimpang bengle bersifat antiinflamasi, ekspektoran, pencahar, membersihkan darah, karminatif, laksatif, dan agen antidisentri (Tim Penyusun, 2012: 210). Khasiat bengle adalah untuk menghangatkan tubuh, mengurangi rasa sakit, mencret, mulas, dan sakit kuning. Dapat juga untuk mengobati demam, sakit kepala, batuk berdahak, perut nyeri, masuk angin, sembelit, cacingan, asma, rematik nyeri otot, dan peluruh lemak (Tim Penyusun, 2012: 210-211).

Kandungan kimia rimpang bengle di antaranya adalah terpinyl acetate, transpiperitol, bornyl acetate, germacrene, methyleugenol, megastigma-trience, lachnophyllum eter, juniper camphor, dan sebagainya (Tim Penyusun, 2012: 211). Berdasarkan uraian diatas, rimpang bengle dapat digunakan untuk menyembuhkan penyakit tidak enak badan, sakit kuning, masuk angin, rewel (tidak dapat tidur), batuk, dan juga batuk serak.

Rimpang dringo (Jawa) atau jeringau digunakan sebagai obat mengurangi radang tenggorokan (Tim Penyusun, 2012: 345). Dengan demikian, dringo yang ditemukan dalam manuskrip dimanfaatkan untuk pengobatan batuk. Rimpang jahe (ginger) merupakan akar tanaman herbal yang termasuk dalam keluarga zingiber officinale roscoe berwarna kuning hingga kemerahan dengan bau yang menyengat. Rimpang jahe merupakan bahan alami mengandung phenolic aktif, seperti shogaol dan gingerol. Rimpang jahe juga bersifat atau memiliki efek antioksidan dan antikanker (Hidayat \& Napitupulu, 2015: 147-148). Rimpang jahe mengandung minyak asiri yang bermanfaat untuk mengobati sakit kepala, rematik, sakit perut, pusing, kolera, penawar racun ular, masuk angin, keseleo, dan bengkak.

Selain itu, rimpang jahe berkhasiat sebagai karminatif, yakni untuk peluruh kentut, mengeluarkan angin. Rimpang jahe berkhasiat sebagai stomakik, yakni menambah nafsu makan dan menguatkan lambung. Juga sebagai stimulan atau sebagai perangsang dan sebagai diaforetik, yakni sebagai peluruh keringat. Rimpang jahe memiliki efek herbal dan dapat untuk mengobati batuk, sakit kepala dan salesma(influensa), mulas, gatal (obat luar), luka (obat luar), sakit kepala (obat luar) dan membangkitkan nafsu makan (Tim Pengobatan Alternatif, 2011: 46-47; Tim Penyusun, 2012: 556).

Rimpang kencur (aromatic ginger, sand ginger) digunakan sebagai obat batuk, peluruh dahak atau pembersih tenggorokan, menghilangkan lendir yang menyumbat hidung, dan menghangatkan badan. Berkhasiat juga untuk menghilangkan gas dari perut dan menangkal radikal bebas (Hidayat \& Napitupulu, 2015: 215-216).

Rimpang kunci berkhasiat untuk batuk kering dan sariawan, kembung dan susah kencing, kurap, batu empedu, dan sari rapet (Widyastuti, Mulyani, \& Ekowati, 2014: 231). Kunyit (curcuma longa) termasuk tanaman fitofarmaka. Bagian yang digunakan untuk herbal adalah rimpangnya. Kandungan rimpang kunyit adalah minyak asiri, kurkumin, dimetoksin kurkumin, arabinosa, fluktosa, glukosa, pati, tanin, magnesium besi, kalsium, natrium, dan kalium (Tim Penyusun, 2012: 118-119).

Berdasarkan kandungan tersebut rimpang kunyit memiliki efek herbal atau khasiat untuk menjaga stamina, hepatoprotektor, diuretik, antioksidan antiradang, immunomodulator, dan 
antikanker (Tim Penyusun, 2012: 117118). Juga, bersifat antiinflamasi, antihiperkolesterolmenia, antiproliferatif, dan antitumor. Rimpang kunyit juga digunakan untuk menurunkan tekanan darah, obat malaria, obat cacing, akit perut, memperbanyak ASI, stimulan, mengobati keseleo, memar, rematik, meredakan batuk, dan antikejang (Tim Penyusun, 2012: 118).

Rimpang lempuyang berkhasiat untuk obat asma, merangsang nafsu makan, merangsang membran mukosa lambung, mengurangi rasa nyeri, pembersih darah, penambah nafsu makan, menurunkan kesuburan pada wanita, pencegah kehamilan, pereda kejang, mengobati penyakit empedu, penyakit kuning, radang sendi, batuk rejan, kolera, anemia, malaria, penyakit syaraf, nyeri perut, mengatasi sakit cacingan, dan masuk angin. Jika rimpang lempuyang digunakan untuk pengobatan atau pemakaian luar bermanfaat untuk mengurangi rasa nyeri (http://www.iptek.net.id/ind/ pd_tanobat/view.php?id=236).

Rimpang sunthi atau jahe sunthi (Jawa) dalam bahasa Latin disebut zingiber officinale var. rubrum (Tim Penyusun, 2012: 162) mempunyai efek herbal antimual, penghangat badan, mengatasi perut kembung, dan merangsang regenerasi sel. Di samping itu, berkhasiat untuk meluruhkan keringat, mengatasi radang tenggorokan, melancarkan pernapasan, dan meningkatkan stamina. Kandungan rimpang sunthi atau jahe sunthi (Jawa) adalah karminativum yang bermanfaat untuk merangsang keluarnya gas dari perut sehingga mampu mengobati masuk angin. Selain itu, juga mengandung gingerol bermanfaat sebagai penghangat badan dan melegakan napas, mineral, vitamin A, ar-curcumene, dan sebagainya (Tim Penyusun, 2012: 163).
Rimpang temulawak (curcumaxanthorrhiza) termasuk dalam fitofarmaka. Artinya, keamanan konsumen akan terjamin karena sudah teruji klinis (Tim Penyusun, 2012: 98). Rimpang temulawak memiliki kandungan antimikroba antibakteri, agen antioksidan, karsinogen, antiproliferasi (penghambatan siklus sel). Juga, terdapat kandungan antiplasmodial, yakni dapat menekan serangan malaria Temulawak berkhasiat untuk menjaga kesegaran badan, mengobati gangguan pencernaan dan manambah nafsu makan, mengobati diare, dan sebagainya.

Adapun umbi dari tumbuhan herbal yang ditemukan adalah bawang merah (brambang) dan bawang putih. Bawang merah (allium cepa) mempunyai efekherbal flavon glikosida yang mempunyai sifat antiradang dan antibakteri. Kandungan kuersetin berkhasiat hipoglikemik, penurun gula darah. Kandungan saponin digunakan untuk mencegah penggumpalan darah. Jika umbi bawang merah diparut dan dicampur dengan minyak dapat untuk menurunkan panas. Bawang merah diparut dan dicampur dengan rimpang kencur dan bahan herbal yang lain dapat digunakan untuk mengobati penyakit batuk. Bawang merah juga berpotensi untuk memblokir kehadiran senyawa karsinogenik (zat pencetus kanker). Senyawa organosulfur dalam umbi berperan aktif sebagai zat kemopreventif pada sel kanker (Tim Penyusun, 2012: 218-219).

Kandungan minyak (berasal dari thiosulfinat dan polysulfida) dalam umbi bawang merah memiliki aktivitas antidiabetes, hipoglikemik, dan hipokolesterol. Bawang merah juga berkhasiat untuk melindungi hati (hepatoprotektor) akibat tetraklorida, yakni dapat menghambat peningkatan GPT plasma dan kerusakan jaringan hati akibat CC14 (Tim Penyusun, 2012: 219-220). 
Selain bawang merah, umbi yang ditemukan adalah bawang putih (allium sativum). Bawang putih meiliki efek herbal, yakni efek antibakteri, antifungi, antivirus, antitumor, dan antidiabetes. Selain itu, juga memiliki efek antikolesterol dan antitrombotik. Umbi bawang putih berkhasiat meredakan tekanan darah tinggi, nyeri kepala, maag, dan sebagai pelindung hati (Tim Penyusun, 2012: 221). Kandungan minyak asiri dalam umbi bawang putih berhasiat sebagai antithepatotoksik, yakni antioksidan dan antigen yang dapat digunakan sebagai pelindungi tubuh dari pengaruh buruk lingkungan. Kandungan organosulfida dalam umbi bawang putih berhasiat membantu hati memproses senyawa kimia beracun, termasuk senyawa kimia yang menyebabkan kanker.

Kandungan sulfur dalam bawang putih merupakan senyawa yang dapat meningkatkan dan mempercepat ke-giatan membran mucus pada saluran pernapasan. Efek tersebut ikut membantu melegakan hidung tersumbat dan mengeluarkan lendir. Kandungan phytochemical sebagai antivirus, yakni dapat membantu membunuh bakteri bakteri dan virus penyebab penyakit (Tim Penyusun, 2012: 222-224).

Selain macam-macam rimpang di atas, racikan jamu yang lain adalah kulit kayu atau kulit batang. Yang termasuk kulit kayu atau kulit batang dari tumbuhan herbal adalah manis jangan cina (kayu manis), kayu legi, kayu timur, kayu ulas, kayu angin, rasuk angin, secang, mesoyi, dan kelembak. Kayu manis (cinnamomum burmannii) memiliki kandungan minyak asiri, safrole, eugenol, kalsium oksalat, sinamaldehide, damar, tanin, dan zat penyamak. Kandungan kayu manis menjadikan kayu manis dapat untuk mengobati untuk penyakit kanker, kolesterol, diare, maag, sakit kepala. Perut kembung, asam urat,dan kencing manis (Hidayat \& Napitupulu, 2015: 181). Adapun efek herbal dalam kayu manis adalah stomatik karminatif, diaforetik, analgesik, antiseptik, dan sebagainyayang berkhasiat antimikroba, anticacing, antidiare, mengobati demam, dan influensa (Tim Penyusun, 2012: 355).

Kandungan kimia kayu angin adalah salazinic acid, protocetraric acid, asam usnic,dan sodium. Kayu angin dimanfaatkan untuk membuat krim, pasta gigi, deodorant, dan produk tabir surya. Kayu angin bermanfaat sebagai makanan suplemen yang dapat menurunkan berat badan (Redaksi Trubus. Tt: 284), berkhasiat untuk mengobati masuk angin, disentri, sariawan, peluruh air seni, batuk, pegal-pegal, mencret, dan disentri (http://jamujawaindonesia.blogspot. com/2012_07_01_archive.html).

Kayu secang memiliki kandungan asam galat, tanin, resin, resorsin, brasilin, brasilein, d-alfa-phellandrene, oscimene, alkaloid, falvonoid, saponin, fenil propana, terpenoid, dan minyak asiri. Kayu secang berkhasiat menghangatkan badan, sebagai antioksidan, sitotoksin (penghancur sel yang terinfeksi virus atau tumor), antitumor, antimikroba, antiviral, dan immunostimulant. Efek antioksidan dan kandungan yang kaya akan flafanoid merupakan suatu faktor yang berpengaruh dalam memberikan aktivitasnya sebagai antiosteoporosis (Hidayat \& Napitupulu, 2015: 185). Kayu secang dapat digunakan untuk mengobati diare (Widyastuti, Mulyani, \& Ekowati, 2014: 224). Selain itu, berkhasiat untuk melancarkan peredaran darah, melarutkan penggumpalan darah, mengurangi pembengkakan, meredakan nyeri, dan menghentikan perdarahan (http://www.deherba.com/secangtanaman-kayu-berkhasiat-obat-antiperdarahan.html). 
Kayu secang juga berkhasiat untuk menghambat pembentukan asam urat yang berlebih di dalam tubuh. Kayu secang yang diseduh dapat digunakan untuk mengobati batuk dan radang, mengatasi rematik dan pembengkakan. Senyawa aktif lain, seperti sappanchalcone dan caesalpin P. juga terbukti memiliki khasiat antiinflamasi, antidiabetes, dan terapi gout secara in vitro (Tim Penyusun, 2012: 482-483).

Di Jawa, secara tradisional kulit kayu mesoyi digunakan untuk menghangatkan perut pada kasus diare/murus dan kejang perut. Bau aromatis yang dihasilkannya menyebabkan bahan ini sering digunakan untuk bedak dicampur dengan cengkeh. Bedak digunakan sebagai penghangat kulit pada saat hujan atau saat udara dingin. Baunya juga merangsang timbulnya hasrat seksual. Kadangkadang kulit mesoyi dibakar supaya menyebabkan bau harum ke seluruh ruang (seperti layaknya kemenyan). Berdasarkan aktivitas biologi yang telah diteliti, kulit kayu mesoyi bersifat sebagai counter irritant (melembabkan pembuluh darah kapiler) dan aromatikum (bahan pewangi, digunakan sebagai campuran ratus wangi (http://mahkotadewa.net/ kesehatan/kayu_mesoyi.html).

Kelembak dapat digunakan sebagai purgatif, antipiretik, antispasmodik, stomakik (Widyastuti, Mulyani, \& Ekowati, 2014: 230). Selain itu, klembak dijadikan bahan campuran jamu lantaran sifatnya sebagai laksatif/penenang. Akar dan batangnya dijadikan sebagai obat sembelit. Kalembak juga digunakan dalam ramuan parem. Herbalis Eropa merekomendasikan kelembak untuk mengobati rematik, batu ginjal, gangguan lever, disentri, dan diare (Redaksi Trubus, Tt: 299).

Dari bagian tanaman herbal yang dimanfaatkan untuk pengobatan tradisional yang lainnya adalah daun. Dedaunan yang ditemukan di dalam racikan/ramuan atau resep jamu yang terdapat dalam manuskrip Jawa tersebut ada bermacammacam. Dedaunan itu adalah daun: pupus anggur, asam (kering), gondhangkasih, inggu prêman, jempinah, pupus kara, karandang, lampes, meniran, oncang (bawang cina), pegagan, pépé, poo, saga (kering), saraban, seruni (merah dan putih), tlukap, trawas, trengguli, urat, waluh, dan waru. Deskripsi dan analisis pengobatan tradisional dari dedaunan yang dapat terjangkau adalah sebagai berikut.

Daun asam jawa atau tamarindus indica digunakan sebagai antiseptik, penghilang mual, penambah nafsu makan, bersifat abortus, dan penghilang rasa sakit. Daun asam bermanfaat untuk obat bisul, koreng, campak, demam, asma, batuk kering, sakit panas, sakit perut, dan bengkak disengat lipan/lebah (Tim Penyusun, 2012: 198-199). Daun asam memiliki kandungan stexin, iovitexin, dan isoorietin. Selain itu, juga mengandung saponin, flavonoid, dan tanin yang bermanfaat untuk meurunkan kolesterol (Tim Penyusun, 2012: 199-200).

Dauninggu (rutaangustifolia) memiliki efek herbal antelmintik, hepatoprotektor, antipiretik, antiradang, antitoksik, antikonvulsan, antispasmodik, abortivum, sedatif, febrifuga, dan karminatif. Daun inggu memiliki kandungan minyak asiri, tanin, ketone, pinane, dan sebagainya. Dengan demikian, daun inggu bermanfaat untuk mengobati sakit kepala, flu, demam, cacingan, bisul, eksim, membersihkan darah, pelebaran pembuluh darah, radang paru, batuk, hepatitis, dan hernia (Tim Penyusun, 2012: 328).

Daun karandang (karandan) atau karanda fruit memiliki kandungan alkaloid. Kandungan itulah yang menjadikan daun 
karandang berkhasiat untuk mengobati sariawan, gatal, dan digigit serangga. Jika, daunnya digerus dan diambil airnya kemudian diminum dapat digunakan untuk mengobati diare, demam, radang mulut, dan sakit telinga (Hidayat \& Napitupulu, 2015: 177).

Daun meniran (phyllanthus niruri) merupakan salah satu bahan jamu yang disebut fitofar maka Indonesia yang mempunyai daun majemuk berseling, berbentuk bulat telur, berwarna hijau, tepi rata, pangkal membulat, ujung tumpul di bawah ibu tulang daun terdapat bulatan kecil-kecil, menggantung. Jamu herbal yang dikategorikan sebagai fitofarmaka, karena sudah melampaui persyaratan aman, klaim khasiat berdasarkan uji klinik (diterapkan pada manusia), telah dilakukan standarisasi terhadap bahan baku yang digunakan, dan memenuhi persyaratan mutu yang berlaku (Tim Penyusun, 2012: 16).

Kandungan daun meniran terdapat methanol dan sesquiterpene (Tim Penyusun, 2012: 72; Hidayat \& Napitupulu, 2015: 274-275). Daun itu berkhasiat untuk mengobati penyakit diare, busung air, infeksi saluran pencernaan, pelancar air seni, pereda demam, dan penyakit yang disebabkan karena gangguan fungsi hati. Juga, bermanfaat untuk mengobati penyakit kuning, kencing nanah (gonorrhoea), diabetes, luka kulit, radang usus, dan penambah nafsu makan (Tim Penyusun, 2012: 74).

Daun pegagan atau centelia asiatica mempunyai efek herbal tonikum, astringent, immuno modulator, antiradang, diuretik, dan antiinfeksi. Di samping itu, daun pegagan juga kaya akan antioksidan sebagai penangkal radikal bebas, Senyawa radikal bebas merupakan pencetus penyakit degeneratif, seperti kanker, kencing manis, gangguan jantung, stroke, dan parkinson. Selain itu, senyawa tersebut juga merangsang produksi enzim antioksidan alami dalam tubuh (Tim Penyusun, 2012: 446). Kandungan asiatikosida dapat meningkatkan daya ingat, konsentrasi, dan kewaspadaan, mengobati radang tenggorokan, menyembuhkan tuberkulosis, mengatasi cacingan,menjaga daya tahan tubuh, mengatasi flu dan batuk (Tim Penyusun, 2012: 448-449).

Daun saga (abrus precatorius)memiliki kandungan protein, vitamin $A$, B1, B6, C, kalsium oksalat, glisirizin, flisirizinat, polygalacturomic acid, saponin, flavonoid, dan pentosan. Daun saga secara empiris berkhasiat sebagai jamu herbal untuk mengobati sariawan, batuk, radang tenggorokan, dan susah buang air besar (Tim Penyusun, 2012: 468-469).

Daun urat (broad-leaved plantain) adalah daun bersatu, roset, berbentuk bulat telur sampai elips, tepi bergerigi tidak beraturan, dan permukaannya gundul. Daun ini memiliki kandungan berupa plantagin, aucubin, ursolic acid, bethasitosterol, hentria-contane, dan plantaglucide yang berkhasiat untuk mengobati penyakit batuk kering, kencing batu, cacingan, wasir, bisul, kulit, dan membersihkan darah luka (Hidayat \& Napitupulu, 2015: 111).

Daun waru (hibiscus tiliaceus) adalah daun yang bertangkai tunggal, berbentuk jantung atau bulat telur, mempunyai pertulangan yang menjari, berwarna hijau, pada bagian bawah daun berambut abu-abu rapat. Daun waru itu mempunyai efek herbal antiradang, ekspektoran, diuretik, dan antipiretik. Daun waru juga mengandung saponin, flavonoid, dan senyawa fenol. Daun tersebut berkhasiat mengurangi radang dan diare, antitoksik, mengeluarkan dahak, diare, mencret, bisul, amandel, menyuburkan rambur, 
dan mendorong pengeluaran air seni (Tim Penyusun, 2012: 538-539).

Bunga dalam tumbuhan herbal yang ditemukan adalah bunga cengkih, apèn, dan waru. Namun, yang terjangkau dalam deskripsi dan analisis ini adalah bunga cengkih dan bunga waru. Bunga cengkih atau syzygium aromaticum memiliki efek herbal yang bersifat mendorong pengeluaran gas (karminatif) dan anti muntah (antiemetik). Kandungan minyak dalam bunga cengkih berkhasiat sebagai antibakteri, antimikroba, amtioksidan, antifungi, antiinflamasi, dan anestesi. Khasiat bunga cengkih yang lainnya adalah untuk mengobati kolera, memberi rasa hangat, air rebusan bunga untuk mengobati campak, iritasi, dan meredakan nyeri, serbuknya membantu mengurangi sakit gigi (Tim Penyusun, 2012: 276).

Bunga waru atau hibiscus tiliaceus berkhasiat untuk meredakan masuk angin dan trakoma. Di samping itu, juga bunga waru dimanfaatkan sebagai ekpektoran, yakni sebagai peluruh dahak, mendorong pengeluaran dahak. Sebagai diuretik, yaitu sebagai peluruh kencing, merangsang pengeluaran air seni, dan anti piretik, yaitu sebagai pereda demam (Tim Penyusun, 2012: 538).

Pemanfaatan tanaman herbal selanjutmya adalah buah. Buah yang digunakan untuk pengobatan tradisional penyakit badan yang diderita oleh anakanak adalah asam (asam jawa), isi bendha, kemukus, klabet, labu putih, pala, isi sawo, dan isi trengguli. Namun, buah dari tumbuhan herbal yang terjangkau adalah sebagai berikut.

Asam atau tamarindus indica adalah salah satu baham alami dari tumbuhan herbal yang ditemukan. Asam jawa memiliki efek herbal yang bersifat analgeik (menghilangkan rasa nyeri). Asam atau asam jawa memiliki efek herbal bersifat analgesik (penghilang nyeri), antipiretik (penurun panas), dan melancarkan sekresi empedu. Khasiat buah asam adalah sebagai antiseptik, penghilang mual, penambah nafsu makan, bersifat abortus, dan penghilang rasa sakit. Khasiat yang lain adalah untuk mengobati encok, eksim, bisul, demam, sariawan, campak, kolesterol tinggi, kencing manis, batuk,asma, dan haid tidak lancar (Tim Penyusun, 2012: 198-199).

Di samping itu, daging buah asam Jawa mengandung bermacam-macam zat asam, di antaranya asam tatrat, malat, sitrat, suksinat, dan asetat. Zat asam itu berkhasiat sebagai pencahar, untuk melancarkan buang air besar dan peredaran darah. Asam jawa juga dimanfaatkan sebagai bahan obat herbal untuk mengatasi berbagai penyakit. Jadi, kemanfaatan asam jawa dalam ramuan pengobatan tradisional Jawa yang digunakan sebagai obat tradisional yang ditemukan adalah sebagai berikut (http://manfaatbuahdaun.blogspot. co.id/2014/10/30-manfaat-asam-jawauntuk-kesehatan.html).

Asam jawa sebagai salah satu bahan jamu yang efektif untuk mengobati sakit panas yang diderita oleh anak-anak. Asam Jawa juga efektif untuk mengobati jika bayi mengalami demam, terkena sakit panas, asma, batuk kering disertai dengan rasa gatal dan perih di tenggorokan serta mengobati penyakit difteri (penyakit saluran pernapasan yang disebabkan oleh bakteri Corynebacterium diphtheriae). Gejalanya berupa sakit tenggorokan, demam, sulit bernapas dan menelan, mengeluarkan lendir dari mulut dan hidung, dan tubuh terasa sangat lemah. Dengan memanfaatkan asam jawa penyakit difteri dapat teratasi.

Kemukus atau piper cubeba memiliki efek herbal sebagai antiinflamasi, 
menambah daya tahan tubuh, antiseptik, diuretik, traccheaspasmolitik, dan antidiare. Kandungan buah kemukus adalah alkaloida piperin, polifenol, terpenterpen, kadinen, kubeda-kamfer, azulen, kubebin, epikubebin,asam-kubeba, damar-kubeba, gom, zat pahit, mangan, dan pati. Senyawa kubebin, epikubebin, dan dihydrokubebin dapat digunakan untuk membantu melonggarkan jalannya pernapasan sehingga kemukus berpotensi sebagai obat asma alternatif. Khasiat buah kemukus adalah untuk mengobati gonorrhoea. Khasiat yang lain adalah untuk meluruhkan dahak, menambah nafsu makan, asma, batuk, dan gangguan pernapasan lainnya (Tim Penyusun, 2012: 389-390).

Buah klabet berkhasiat sebagai peluruh kentut (karminatif), tonikum (Depkes RI, 1977 dalam Widyastuti, Mulyani, \& Ekowati, 2014: 241). Selain itu, buah klabet dapat digmanfaatkan untuk mengobati asma, batuk, haid tidak teratur, pencernaan tidak baik, radang lambung, sakit kerongkongan, wasir, bisul (obat luar), rambut rontok (obat luar), rematik atau nyeri otot (obat luar), dan pelembut kulit (untuk bahan kosmetika) (http:// www.naturelifeshop.com/klabet.html).

Labu putih atau sechium edule (jacq) sw.: chayate adalah tumbuhan merambat di tanah, memiliki buah dengan daging buah berwarna putih pucat. Buahnya mengandung alkaloid saponin, tanin, asam folat, berbagai mineral, dan vitamin. Selain itu, juga mengandung serat yang tinggi, sehingga aman dimakan oleh siapa saja. Buah labu putih berkhasiat untuk mengobati kolesterol, hipertensi, asam urat, diabetes, dan sariawan (Hidayat \& Napitupulu, 2015: 245-246). Alkaloid berkhasiat untuk memperlancar darah dan menetralisir racun-racun dalam tubuh. Saponin berperan sebagai penghambat dan pencegah penyerapan kolesterol dalam darah, tanin sebagai antimikrobia (Suriana \& Shobariani, 2013: 156-158).

Selain itu, labu putih juga memiliki kandungan antioksidan, yakni apigenin, luteolin, dan vitamin C. Ketiga jenis antioksidan itu bermanfaat untuk melawan dan membersihkan radikal bebas penyebab kanker yang ada di dalam tubuh. Kandungan potassium dalam labu putih merupakan salah satu jenis elektrolit yang bermanfaat sebagai sumber stamina tubuh. Kandungan serat dalam daging labu dapat membantu melancarkan proses pencernaan di dalam tubuh, sehingga dapat mencegah terjadinya sembelit. Zat diuretik yang ada dalam labu putih bermanfaat untuk mengobati gangguan pada perut, yakni perut kembung. Juga, memiliki kandungan berbagai mineral seperti potassium, zat besi, fosfor, dan mineral lainnya dibutuhkan oleh tubuh untuk menjaga sistem kekebalan, menjaga kekuatan dan kepadatan tulang dan gigi, mempertahankan kesehatan metabolisme (http://manfaat.co.id/15-manfaat-labusiam-bagi-kesehatan).

Pala atau myristica fragrans mempunyai efek herbal yang bersifat stomakik, karminatif, sedatif, dan stimulan. Kandungan buah pala berupa minak asiri, minyak lemak, zat samak, saponin, miristisin, elemisin, pektin, hars, lamonena, asamtetradekanoid, dan asam aleanolat. Khasiat buah pala adalah untuk mengobati gangguan pencernaan, seperti disentri, maag, kembung, mencret, dan mual. Air rebusan buah pala dapat digunakan sebagai obat untuk mengatasi rematik. Di samping itu, khasiat buah pala adalah untuk mengendurkan syaraf sehingga baik untuk penderita hipertensi (Tim Penyusun, 2012: 438-440).

Selanjutnya, pemanfaatan tumbuhan herbal yang ditemukan adalah bagian biji. 
Biji yang dimanfaatkan untuk pengobatan tradisional Jawa terhadap penyakit badan yang diderita oleh anak-anak adalah adas, jinten, kedhawung, ketumbar, dan mungsi. Biji adas atau foeniculum vulgare memiliki kandungan limonena, minyak lemak, stigmasterol, kamfena, limonena, arginin, umbeliferona, gula, saponin, flavonoida, polifenol, anetol, fenkom, pinen, dipenten, felandren, dan sebagainya. Biji adas memiliki efek herbal yang berkhasiat untuk menghilangkan rasa nyeri, mengurangi pembengkakan, melancarkan peredaran darah, peluruh kentut, menambah nafsu makan, mengobati gangguan lambung, dan merangsang produksi ASI (Tim Penyusun, 2012: 174-176).

Kandungan minyak asiri dalam adas berkhasiat sebagai peluruh dahak, stimulan, laksatif, diuretik, dan antiperadangan. Kandungan minyak adas berupa anetol, fenkom, chavikot, dan anisaldehit yang berkhasiat untuk menyejukkan saluran pencernaan dan bekerja sebagai perangsang nafsu makan. Ramuan dengan biji adas berkhasiat untuk mengobati sembelit, diare, perut kembug, rematik, batuk atau peluruh dahak, sesak napas, dan keracunan (Tim Penyusun, 2012: 176).

Jinten yang ditemukan dalam penyakit badan ini ada tiga macam, yaitu jinten, jinten hitam, dan jinten putih. Jinten atau coleus amboinicus memiliki efek herbal antibakteri, haemoptosis, karminatif, laktagoga, dan anti piretik. Kandungan dalam jinten adalah alpha-tujene, bergamotene, crategolic, acig, euschapic, cumene, oleanolic, minyak esensial, dan sebagainya. Jinten dimanfaatkan karena berkhasiat untuk menyembuhkan susah buang air seni (anyang-anyagen) karena gangguan inveksi saluran kemih (Tim Penyusun, 2012: 347-348). Selain itu, jinten juga mengandung phythosterin-B yang berkhasiat untuk mengobati asma, batuk, perut kembung, sakit kepala, sariawan, demam, luka, dan borok (Arisandi \& Andriani, 2011: 174).

Jinten hitam atau nigella damascena I memiliki khasiat untuk meningkatkan sistem kekebalan tubuh, meningkatkan jumlah produksi ASI, mengobati asma dan alergi, kanker, gangguan pencernaan, peradangan, mencegah kanker serviks, mengobati wasir, mengobati kanker payudara, sebagai bahan dengan herbal lain untuk menurunkan kolesterol, hipertensi, dan gula darah (http://www. carakhasiatmanfaat.com/artikel/khasiatmanfaat-jinten-hitam-untuk-kesehatandan-pengobatan.html). Jintan putih atau cuminum cyminum mengandung minyak menguap yang berkhasiat mengobati sakit jantung, haid tidak lancar, sulit tidur dan sebagai jamu putri (Arisandi \& Andriani, 2011:172).

Kedhawung atau parkia timoriana yang ditemukan untuk pengobatan tradisional dimanfaatkan pada bagian bijinya. Kandungan dalam biji kedhawung adalah saponin dan flavonoid. Khasiatnya adalah sebagai antibakteri dan dimanfaatkan sebagai obat untuk sakit disentri. Jika biji kedhawung direndam dapat berkhasiat untuk pengobatan sakit telinga. Biji kedhawung juga berkhasiat untuk mengobati infeksi kulit, bisul, cacingan, dan sakit perut (kembung, mulas atau nyeri perut). Biji kedhawung memiliki khasiat untuk obat batuk, dapat menyembuhkan demam pada waktu nifas, mengurangi nyeri pada saat akan persalinan dan pada saat haid, mengobati dan mengurangi rambut kusam, membantu menyembuhkan penyakit radang usus, kolera, penyakit jantung, dan dapat juga dimanfaatkan sebagai obat radang lambung. (Hidayat \& Napitupulu, 2015: 193-194). 
Ketumbar atau coriandrum sativum memiliki efek herbal sebagai karminatik, laktago, stomakik, antipasmodik, diuretik, digestive, decongestan, antiinflamasi, antioksidan, antibakteri, antijamur, dan diaphoretik. Biji ketumbar memiliki kandungan resin, malic, acid, alkaloid, sabinene, mircene, dan sebagainya. Khasiat biji ketumbar adalah sebagai obat masuk angin, influensa, meredakan sakit kepala/pusing, gangguan pencernaan terutama lambung, mual, haid tidak teratur, dan sariawan. Di samping itu, juga berkhasiat untuk mengobati wasir, menurunkan tekanan darah/hipertensi, campak, keracunan, dan radang (Tim Penyusun, 2012: 395-396).

Mungsi dalam bahasa Latin disebut carum copticum benth. Biji mungsi me-miliki khasiat sebagai obat herbal tradisional yang digunakan untuk mengobati ke-guguran, menyusui, menopause, bersalin, jamu galian remaja, desentri (http://jamujawaindonesia. blogspot.com/2012/09/mungsi-carumcopticum-l-benth.html).

Racikan jamu di atas diramu dengan menggunakab bahan pelengkap. Bahan pelengkap dalam ramuan jamu yang ditemukan ada lima macam, yaitu dupa cina, garam, inggu, tembakau (sata awon), dan terasi merah. Dupa cina atau kemenyan, kemenyan madu (Jawa) berkhasiat sebagai penenang, penambal gigi, antimikrobia, antibengkak, pengawet, obat luka, pilek, bronchitis.

Inggu atau Ruta angustifolia [L.] Pers. Inggu mengandung minyak yang esensialnya berkhasiat dan dapat digunakan untuk pembuatan parfum dan kosmetik. Selain itu, inggu juga mengandung minyak atsiri yang berkhasiat untuk mengobati demam, influenza, batuk, radang paru, ayan (epilepsi), hepatitis, kejang pada anak, kecikutan (singultus, hiccup), kolik, cacingan, histeri (hysteria), nyeri ulu hati, nyeri dada, hernia, bisul, haid tidak teratur, tidak datang haid (amenorrrhea). Inggu dapat untuk mengobati radang kulit bernanah, memar akibat benturan benda keras, gigitan ular berbisa dan serangga, keracunan obat atau racun, pelebaran pembuluh darah balik (vena varikosa), dan radang vena (flebitis) (Arisandi \& Andriani, 2011: 137).

Garam digunakan sebagai bahan pelengkap ramuan jamu karena memiliki efek antibakterial. Dengan kandungan antibakteri, garam memiliki manfaat untuk meredakan ruam di kulit akibat alergi dan infeksi, dapat meredakan rasa sakit dan linu, dan secara alami dapat menyerap minyak dari kulit sehingga mampu mencegah timbulnya jerawat (http://kabarimbo.com/5-manfaatgaram-untuk-kulit/). Garam yang sudah dicampur dengan air dapat menghilangkan kegatalan di kulit. Dengan memakan garam dapat untuk mengembalikan tenaga, menyembuhkan bengkak, dapat membantu pengeluaran racun yang ada di dalam perut (http://mustahabbah. blogspot.co.id/2015/10/fakta-tentangmanfaat-garam-untuk.html).

Tembakau (sata awon) memiliki efek herbal sebagai obat antiinflamasi (terbentuk dari zat biologis aktif interleukin-10 (IL-10), sitokin yang terdapat dalam tembakau), vektor, sitokin, dan autoimun. Selain itu, juga mengandung saponin, flavonoid, minyak terbang (pada kulit, batang dan daun), polifenol (pada kulit batang dan daun), dan bersifat antiinflamasi. Kandungan yang terdapat di dalam tembakau adalah nikotin, protein, alkaloid, vektor, interleukin-2, dan membantu memproduksi melanin pada tubuh manusia. Kandungan nikotin dalam daun tembakau berkhasiat untuk mengurangi rasa sakit serta membantu 
menarik keluar racun dan menyembuhkan luka luar.

Daun tembakau dengan campuran Leptotaenia multifida dapat membantu penyembuhan asma dan TBC. Daun tembakau juga dapat digunakan untuk membersihkan saluran hidung. Jika daun tembakau dibuat bubuk dapat digunakan untuk membersihkan gigi dengan cara digosokkan. Daun tembakau dimanfaatkan untuk memproduksi obat-obatan dalam mengobati penyakit autoimun dan antiinflamasi, termasuk diabetes, HIV, dan kanker. Daun dari tanaman tembakau adalah tempat penyimpanan utama untuk protein. Kandungan alkaloid dimanfaatkan untuk melindungi tubuh dari ancaman biologis termasuk anthrax, botulisme, plague, ebola, hantavirus, dan racun risin. Air daun tembakau berkhasiat sebagai pengusir gigitan lintah.

Vektor yang berasal dari virus tembakau dikombinasikan dengan gen yang berguna, misalnya, salah satu yang mengatur produksi protein untuk manusia interleukin-2, yang sedang digunakan dalam pengobatan kanker. Tanaman tembakau dimodifikasi secara genetik dapat untuk memproduksi obat-obatan yang digunakan untuk beberapa penyakit autoimun dan antiinflamasi, termasuk diabetes. Tanaman tembakau transgenik dapat menghasilkan zat biologis aktif interleukin-10 (IL-10) dan sitokin, yakni sebagai antiinflamasi yang kuat (http:// manfaat.co.id/manfaat-tembakau; http://www.nangimam.com/2014/01/ kandungan-dan-manfaat-tembakau.html).

Cairan yang digunakan sebagai campuran bahan ramuan jamu terdapat tujuh macam, yaitu air jeruk nipis, air jeruk purut, air panas dan air tawar, air perasan daun iler, air susu ibu, dan cuka. Campuran berupa air yang berasal dari jeruk nipis. Jeruk nipis atau citrus aurantifolia memiliki efek herbal yang dimanfaatkan untuk bahan kosmetik, yakni sebagai bahan untuk memperkecil pori-pori wajah, membersihkan, dan menyegarkan (astringen). Lime oil yang terpadat di dalam buah jeruk nipis memiliki khasiat sebagai antiseptik, antivirus, astringen, hemostatik, restoratif, dan tonikum. Khasiat sebagai antiseptik, yakni kandungan jeruk nipis dapat digunakan untuk mematikan kumangu. Khasiat sebagai antivirus, yakni kandungan dalam jeruk nipis dapat digunakan untuk mematikan virus.

Khasiat sebagai hemostatik, yakni kandungan dalam jeruk nipis dapat dimanfaatkan untuk menghentikan pendarahan. Khasiat sebagai tonikum, yakni kandungan dalam jeruk nipis berkhasiat untuk menguatkan atau meningkatkan daya tahan tubuh (Tim Penyusun, 2012: 340, 556). Senyawa aktif yang terdapat di dalam jeruk nipis adalah hesperidin. Hesperidin bermanfaat sebagai bahan antiinflamasi, yakni mengurangi pembengkakan, menghambat proliferasi sel kanker, dan menunda tumorigenesis. Air jeruk nipis digunakan sebagai pengobatan tradisional karena dapat digunakan sebagai obat batuk, obat penurun panas, dan obat pegal linu. Selain itu, jeruk nipis juga bermanfaat sebagai obat disentri, sembelit, ambeien, haid tidak teratur, difteri, jerawat, kepala pusing/vertigo, suara serak karena batuk, menambah nafsu makan, mencegah rambut rontok, ketombe, flu/demam, mimisan, penyakit anyang-anyangen, bau badan, dan radang hidung (Tim Penyusun, 2012: 341).

Bahan campuran lain berupa air yang berasal dari jeruk purut. Jeruk purut atau citrus hystrix memiliki efek herbal yang bekerja sebagai stimulan antioksidan, antiinflamasi, dan astringen. Kandungan jeruk purut adalah flavonoid, glikosida, 
kumarin, bergamottin, oxypeucedain, minyak asiri (terdiri atas citronelial, geranial, dan d-limonene). Khasiat jeruk purut dimanfaatkan untuk mengobati flu dan kelelahan badan. Kandungan minyak asiri digunakan untuk mengendorkan urat-urat yang tegang. Selain itu, jeruk purut berkhasiat sebagai obat flu, demam, hipertensi dan diare (Tim Penyusun, 2012: 342-342).

Air adalah bahan alami yang mengandung mineral. Khasiat air tawar (air masak yang sudah dingan) adalah untuk mencairkan ramuan jamu sehingga kandungan alami dalam jamu herbal tidak terlalu pekat atau ekstrak (http://www. zonanesia.net/2016/03/manfaat-minumair-putih-setelah-bangun.html). Jika campuran ramuan jamu dengan air yang sudah dipanaskan maka dapat bermanfaat untuk proses detox alami bagi tubuh. Detox merupakan cara tepat untuk mengeluarkan racun yang ada di dalam tubuh. Jadi, bahan pelengkap yang berupa cairan baik air tawar maupun air panas bermanfaat sebagai pengobatan tradisional (http:// manfaat.co.id/20-manfaat-minum-airhangat-bagi-kesehatan).

Bahan campuran lain berupa air yang berasal dari air perasan daun ilèr. Ilèr atau Coleus scutellarioides memiliki efek herbal sebagai karminatif, antimikroba, antioksidan, dan emmenagoga. Tumbuhan herbal iler memiliki kandungan berupa karvakrol, diterpenoid, timol, metil eugenol, etil salsilat, alkaloid, dan mineral. Daun iler berkhasiat untuk mengobati diabetes, diare, demam, ambeien, wasir, anticacing gelang, keputihan, dan haid tidak lancar. Selain itu, juga berkhasiat untuk obat sinusitis, diare, asma, radang mata, insomia, luka berdarah, dan memar (Tim Penyusun, 2012: 325-327).

Air susu ibu mengandung laktosa, yakni jenis karbohidrat. Karbohidrat adalah sumber energi utama bagi tubuh. Laktosa yang memberikan rasa manis, akan diolah menjadi glukosa. Glukosa adalah gula sederhara (monosakarida dalam ai susu ibu. Air susu ibu (ASI) dimanfaatkan sebagai bahan cairan pelengkap ramuan jamu karena mengandung laktosa dengan toleransi tinggi dapat mengurangi kekurangan kalsium sehingga terhindar dari masalah kesehatan lainnya seperti diare atau masalah gastrointestinal lainnya. Di samping glukosa, air susu ibu juga mengandung galaktosa, yakni berperan dalam perkembangan sistem saraf (satuan serat yang menggunakan sinyal kimia). Nutrisi dalam air susu ibu bermanfaat untuk membantu penyerapan kalsium.

Kalsium adalah mineral penting yang dibutuhkan manusia. Selain kalsium, ASI juga mengandung magnesium, yakni diperlukan untuk pembentukan protein dan tulang di masa pertumbuhan bayi. Kandungan yang lain dalam ASI adalah lemak, yakni zat gizi sebagai sumber energi utama yang berperan dalam pengaturan suhu tubuh; asam lemak (penting untuk melindungi organ); asam linoleat; dan asam alda linoleat yang diolah oleh tubuh menjadi AA dan DHA yang sangat penting untuk perkembangan otak bayi. ASI juga mengandung oligosakarida, yakni komponen bioaktif di ASI yang berfungsi sebagai prebiotik. Prebiotik merupakan serat pangan yang berfungsi untuk meningkatkan jumlah bakteri mikroorganisme yang bermanfaat bagi tubuh (http://www.nutriclub.co.id/ kategori/bayi/nutrisi/).

Kandungan ASI yang lainnya adalah kandungan gangliosida (GA), yakni berperan untuk pembentukan memori dan fungsi umum otak besar serta sebagai alat konektivitas sel otak bayi sehingga dapat meningkatkan kecerdasan otak pada anak. Dalam kolostrum terdapat protein, vitamin 
A, karbohidrat, dan lemak rendah yang berguna bagi bayi di hari-hari pertamanya. Selain kolostrum, ASI juga mengandung taurin, decosahexanoic acid (DHA), dan arachidonic acid (AA). Ketiga kandungan tersebut sangat diperlukan untuk pembentukan sel-sel otak bayi. Kelebihan utama ASI lainnya yang tidak dimiliki oleh susu lainnya adalah zat imunologik. ASI mengandung zat antiinfeksi yang bersih dan bebas kontaminasi. Zat imun itu ada pada immunoglobulin, sekretori, dan laktoferin (http://dokter-medis.blogspot. co.id/2009/11/kandungan-gizi-dalamair-susu-ibu.html).

Air cuka memiliki kandungan asam citrit yang sangat tinggi yang bermanfaat untuk membantu tubuh dalam menyerap kalsium, sehingga terhindar dari osteoporosis (pengeroposan tulang). Kandungan antibakteri dalam cuka berkhasiat untuk mengobati sakit tenggorokan akibat infeksi. Kandungan asam asetik dalam cuka bermanfaat sebagai non-toxic desinfektan, yakni dapat digunakan untuk membunuh bakteri tuberculosis. Kandungan keasamannya dalam cuka dapat menurunkan $\mathrm{pH}$ pada jaringan dan mencegah tumbuhnya bakteri pada permukaan jaringan (http:// manfaat.co.id/manfaat-cuka-dapur).

Cara pengolahan bahan racikan jamu untuk penyakit badan ada delapan macam, yakni dengan dibakar, digigit-gigit, digoreng, dihaluskan (dipipis, didheplok, digerus), dijemur, dikukus, dan direndam. Dengan cara dibakar, bahan-bahan jamu akan menghasilkan kandungan bahan jamu yang tidak tajam dan sudah terfermentasi dengan khasiat bahan jamu yang menjadi setengah matang, calon arang, dan arang. Olahan dari bahan jamu yang dibakar akan menghasilkan activated charcoal atau karbon aktif. Karbon aktif itu berkhasita dapat menyerap berbagai unsur zat beracun (http://manfaat.co.id/ manfaat-arang-batok-kelapa).

Dengan cara digigit-gigit terhadap bahan jamu, maka kandungan yang terdapat di dalamnya akan terasa langsung khasiatnya. Apabila bahan jamu itu langsung ditelan maka kandungannya akan langsung masuk ke dalam tubuh. Namun, jika bahan jamu digigit-gigit kemudian dikeluarkan lagi maka bahan itu sudah tercampur dengan air liur yang mengandung enzim dan khasiatnya dapat dimanfaatkan untuk mengobati penyakit. Bahan jamu yang diolah dengan cara digoreng, maka kandungan bahan jamu itu bertambah bahan lain, yaitu minyak kelapa. Minyak kelapa memiliki kandungan endosperium yaitu kaya akan kandungan enzimnya (Suriana \& Shobariani, 2013: 138) yang bermanfaat untuk mengobati penyakit.

Pengolahan bahan jamu dengan cara dihaluskan (dipipis, didheplok, digerus), maka akan menghasilkan semua kandungan yang terdapat di dalam ramuan jamu dapat dimanfaatkan secara utuh. Apabila ramuan jamu dihaluskan dengan tambahan cairan, maka selain untuk memudahkan cara penghalusannya juga akan mengangkat semua kandungan dalam bahan jamu tersebut. Di samping itu, bahan cairannya juga akan menambah kemanfaatan khasiat bahan jamu herbalnya. Bahan jamu yang harus dijemur dahulu sebelum dimanfaatkan, karena dengan dijemur bahan jamu akan terkena langsung sinar matahari yang mampu membunuh bakteri penyakit, virus, dan jamur juga dimungkinkan akan lebih tahan lama (http://doktersehat.com/ manfaat-sinar-matahari-di-pagi-haribagi-kesehatan/).

Bahan jamu yang diolah dengan cara dikukus dahulu, karena dengan cara itu bertambah aroma tanakan nasi 
dan menjadikan bahan jamu menjadi setengah matang. Bahan jamu setengah matang menghilangkan aroma tajam, tetapi kandungannya tetap utuh. Bahan jamu yang diolah dengan cara direbus, agar bahan jamu menjadi matang dan kandungannya bercampur dengan air. Air rebusan jamu memiliki ekstrak kandungan bahan jamu, sehingga lebih mudah untuk mengobatannya. Yang terakhir adalah cara olah bahan jamu, yaitu dengan direndam. Bahan jamu yang direndam dimaksudkan agar bahan jamu lebih lunak sehingga lebih mudah untuk pengolahannya. Dengan cara direndam diharapkan kandungannya tetap utuh.

Cara pemberian jamu terhadap penderita ada tujuh macam yaitu di-borehkan, di-cekok-kan, diminumkan, di-paramkan, di-pupuk-kan, dan di-tapel-kan. Pemberian jamu pada penderita anak-anak dengan cara di-borèh-kan dengan maksud agar khasiat jamu dapat terserap pada seluruh tubuh yang terkena borèh. Dengan cara borèh dimaksudkan penyakitnya akan segera sembuh. Pemberian jamu pada penderita anak-anak dengan cara di-cekok-kan adalah memasukkan cairan ramuan jamu yang di tempatkan pada kain kemudian diperaskan langsung ke dalam mulut dengan maksud agar khasiat jamu dapat langsung terserap pada seluruh tubuh dan dapat dirasakan khasiatnya. Dengan cara di-cekok-kan anak akan langsung meminumnya dan dimungkinkan tidak menolak rasa pahit dari jamu, sehingga pengobatannya akan berhasil dapat menyembuhkan penyakitnya.

Pemberian jamu pada penderita anak-anak selain dengan cara di-cekok-kan adalah dengan diminumkan. Sama halnya dengan cara di-cekok-kan, meminumkan jamu juga dengan maksud agar khasiat jamu dapat langsung terserap pada seluruh tubuh dan dapat dirasakan khasiatnya.
Dengan cara meminumnya khasiat jamu akan langsung masuk ke dalam tubuh, sehingga pengobatannya dimungkinkan akan berhasil dapat menyembuhkan penyakit. Seperti dengan cara di-borèhkan, di-param-kan pun fungsinya sama, yakni membalurkan ramuan jamu (sebagai obat luar) pada bagian tubuh yang sakit. Dengan demikian, ramuan jamu akan langsung dapat dirasakan khasiatnya sehingga dimungkinkan dapat berhasil menyembuhkan penyakit. Cara pemberian ramuan jamu (sebagai obat luar) adalah dengan cara di-pupuk-kan.

Pemberian ramuan jamu dengan cara di-pupuk-kan adalah pemberian ramuan yang ditempelkan di atas ubun-ubun anak-anak. Dengan cara penyembuhan seperti itu adalah untuk menurunkan panas atau demam pada anak, sehingga langsung dapat dirasakan khasiat ramuan jamunya. Cara pemberian ramuan jamu yang demikian sangat efektif untuk penyembuhan penyakit. Cara pemberian ramuan jamu tradisional yang terakhir adalah di-tapel-kan. Pemberian ramuan jamu dengan cara di-tapel-kan adalah rauan jamu diletakkan pada seputar perut kemudian dibalut dengan kain. Cara demikian juga efektif untuk merasukkan ramuan jamu, sehingga langsung terkena pada sasaran bagian tubuh yang sakit. Pemberian ramuan jamu dengan cara ditapel-kan memungkinkan penyembuhan penyakit lebih cepat.

\section{SIMPULAN}

Berdasarkan uraian di atas dapat ditarik simpulannya bahwa pengobatan tradisional Jawa untuk penyakit (badan yang diderita oleh anak-anak) yang ditemukan di dalam manuskrip SPJJ I meliputi lima macam. Kelima macam pengobatan tradisional Jawa itu adalah sebagai berikut. Pertama, bahan jamu 
dalam racikan untuk penyakit badan terdiri atas tanaman obat (tumbuhan herbal) yang ditemukan terdiri atas akar, rimpang, umbi, kulit kayu, batang, daun, bunga, buah, dan biji. Kedua, pelengkap jamu racikan jamu yang ditemukan ada lima macam, yaitu dupa cina, garam, inggu, tembakau (sata awon), dan terasi merah. Adapun bahan nontanaman ditemukan ada delapan macam yaitu brang, bekicot, cindhe amoh (kain) yang sudah robek, kopyah amoh (topi/penutup kepala yang sudah sobek), kreweng (pecahan genteng), tuma (kutu kepala), paku, dan sumbu cina.

Ketiga, cairan yang digunakan sebagai campuran bahan ramuan jamu terdapat tujuh macam yaitu air jeruk nipis, air jeruk purut, air panas, air perasan daun iler, air susu ibu, air tawar, dan cuka. Keempat, cara pengolahan bahan racikan jamu untuk penyakit badan ada delapan macam yaitu dibakar, digigit-gigit, digoreng, dihaluskan (dipipis, didheplok, digerus), dijemur, dikukus, direbus, dan direndam. Kelima, cara pemberian jamu terhadap penderita ada tujuh macam yaitu di-borèh-kan, dicekok-kan, diminumkan, di-param-kan, di-pupuk-kan, dan di-tapel-kan.

Melalui artikel ini, kami menyampaikan ucapan terima kasih kepada semua pihak yang berperan serta dalam penelitian tahap pertama dan tahap kedua. Tulisan ini ditulis dari hasil Penelitian Fundamental dengan dana Tahun Anggaran 2015 dan 2016 dengan judul "Pengobatan Tradisional Jawa pada Manuskrip-manuskrip Mangkunegaran, Kasunanan Surakarta, dan Museum Radyapustaka". Pertama, kami menyampaikan ucapan terima kasih kepada Direktorat DP2M DIKTI yang telah menghibahkan dana melalui Penelitian Fundamental. Kedua, kami menyampaikan ucapan terima kasih kepada Rektor
Univeritas Negeri Yogyakarta lewat Ketua Lembaga Penelitian dan Pengabdian kepada Masyarakat UNY yang telah memfasilitasi seluruh penelitian ini. Selanjutnya, ucapan terima kasih disampaikan kepada reviewer, baik dalam seminar awal penelitian, monev internal, monev eksternal maupun seminar akhir untuk persiapan pembuatan laporan akhir penelitian yang telah membaca, mengoreksi, dan memberi masukan terhadap penelitian dan tulisan ini. Ketiga, ucapan terima kasih juga kami sampaikan kepada semua pihak pemberi data dan informasi serta pihak-pihak lainnya yang tidak dapat kami sebutkan satu demi satu dalam penelitian dan tulisan ini. Akhirnya, kepada siapa saja penulis telah berhutang budi, terutama yang tidak dapat disebutkan satu demi satu di sini, penulis menghaturkan terima kasih yang tiada terhingga. Kiranya hanya Allah SWT, yang dapat memberikan imbalan yang berlebih.

\section{DAFTAR PUSTAKA}

Arisandi, Y., \& Andriani, Y. 2011. Khasiat Berbagai Tanaman untuk Pengobatan Berisi 158Jenis Tanaman Obat. Jakarta: Eska Media.

Baried, S. B., Soeratno, S. C., Sawoe, Sutrisno, S., \& Syakir, M. 1985. Pengantar Teori Filologi. Pusat Pembinaan dan Pengembangan Bahasa, Departemen Pendidikan dan Kebudayaan Jakarta.

Baried, S. B., Soeratno, S. C., Sawoe, Sutrisno, S., \& Syakir, M. 1994. Pengantar Teori Filologi. Yogyakarta: Badan Penelitian dan Publikasi Fakultas (BPPF) Seksi Filologi, Fakultas Sastra Universitas Gadjah Mada.

Djamaris, E. 2002. Metode Penelitian Filologi. Jakarta: CV Manasco. 
Hidayat, R. S., \& Napitupulu, R. M. 2015. Kitab Tumbuhan Obat. Jakarta: AgriFlo.

Istanti, K. Z. 2010. Filologi Studi Teks Sastra Melayu dan Jawa. Seri Kajian. Yogyakarta: Elmatera.

Rahimsyah, M. B, \& Hartatik, A. S. 2006. Aneka Resep Obat Kuno yang Mujarab. Surabaya: Penerbit Karya Gemilang.

Saputra, K. H. 2008. Pengantar Filologi Jawa. Jakarta: Wedatama Widya Sastra

Suparmi, \& Wulandari, A. 2012. Herbal Nusantara 1001 Ramuan Tradisional Asli Indonesia. Yogyakarta: Andi Offset.

Suriana, N., \& Shobariani, I. 2013. Ensiklopedia Tanaman Obat. Malang: Rumah Ide.
Tim Pengobatan Alternatif. 2011. Obat Herbal Luar Biasa!. Surabaya: Cv. Pustaka Agung Harapan.

Tim Penyusun. 2012. Herbal Indonesia Berkhasiat: Bukti Ilmiah \& Cara Racik (Vol. 10). Depok: PT. Trubus Swadaya.

Undang-Undang Nomor 9 Tahun 1960 tentang Pokok-Pokok Kesehatan.

Undang-Undang Nomor 23 Tahun 1992 tentang Kesehatan.

Widyastuti, S. H., Mulyani, H., \& Ekowati, V. I. 2014. Fitotherapy dalam Manuskripmanuskrip Jawa. Laporan Penelitian LPPM UNY.

Zulkifli. 2004. Pengobatan Tradisional sebagai Pengobatan Alternatif Harus Dilestarikan. Jakarta: PT Agromedia Pustaka. 